\title{
Citrus Blackfly Parasitoid, Encarsia opulenta (Silvestri) (Insecta: Hymenoptera: Aphelinidae) ${ }^{1}$
}

Ru Nguyen ${ }^{2}$

\section{Introduction}

Encarsia opulenta (Silvestri) is one of the most effective parasitoids of the citrus blackfly, Aleurocanthus woglumi Ashby (Homoptera: Aleyrodidae). It was discovered by Silvestri on $A$. incertus collected in Van-Phu (Vietnam) (Silvestri 1927). In 1950, E. opulenta from Saharanpur (India) were released for the control of $A$. woglumi in Mexico (Flanders 1969). The parasite was then introduced to Texas in 1971 (Summy et al. 1983), and Florida in 1976 (Hart et al. 1978) to suppress and maintain under the economic threshold the population of the citrus blackfly in these states.

\section{Distribution}

Encarsia opulenta has been reported as native to Asia (Vietnam and India) (Silvestri 1927, Smith et al. 1964), and was introduced to Barbados, Cuba, Salvador, Kenya, Jamaica, Oman, Mexico, Venezuela, and USA (Texas and Florida) to control the citrus blackfly. In Florida, the parasite is found in South and Central Florida where the citrus blackfly occurs (Nguyen et al. 1983).

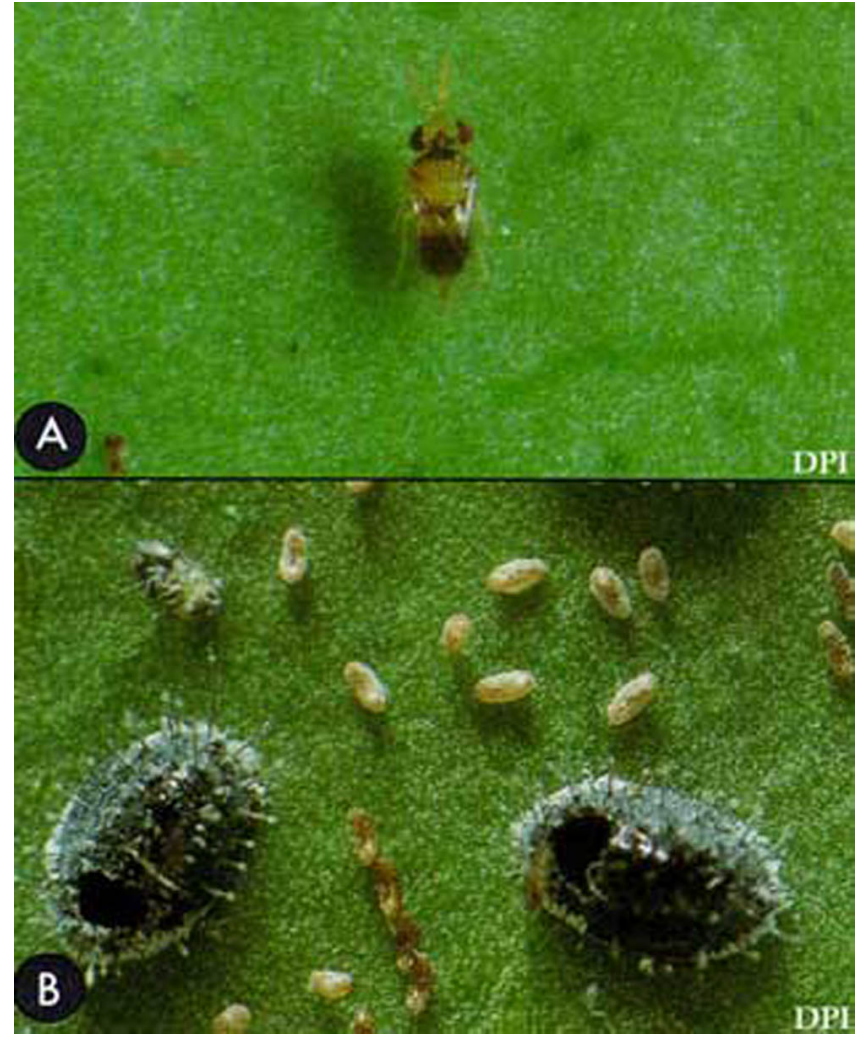

Figure 1. (A) Adult Encarsia opulenta (Silvestri), and (B) pupal cases of the citrus blackfly, Aleurocanthus woglumi Ashby, from which the parasitoid has emerged. Credits: Division of Plant Industry

1. This document is EENY-242 (originally published as DPI Entomology Circular 301), one of a series of Featured Creatures from the Entomology and Nematology Department, Florida Cooperative Extension Service, Institute of Food and Agricultural Sciences, University of Florida. Published: October 2001. This document is also available on Featured Creatures Website at http://creatures.ifas.ufl.edu. Please visit the EDIS Website at http://edis.ifas.ufl.edu and the Entomology and Nematology Department website at http://entnemdept.ifas.ufl.edu/. 2. Ru Nguyen, Florida Department of Agriculture and Consumer Services, Division of Plant Industry, Gainesville, FL.

The Institute of Food and Agricultural Sciences (IFAS) is an Equal Employment Opportunity - Affirmative Action Employer authorized to provide research, educational information and other services only to individuals and institutions that function without regard to race, creed, color, religion, age, disability, sex, sexual orientation, marital status, national origin, political opinions or affiliations. For information on obtaining other extension publications, contact your county Cooperative Extension Service office. Florida Cooperative Extension Service / Institute of Food and Agricultural Sciences / University of Florida / Larry R. Arrington, Interim Dean 


\section{Description}

Female small (1.10 mm long). Thorax whitish to pale yellowish. Antennae $0.8 \mathrm{~mm}$ long, 8 segmented, and the 1 st flagellum shorter than pedicel or other flagella. Wing slightly shady in the center. Abdomen with segments 3 to 6 dark brown, remainder yellowish. Ovipositor dark, $0.5 \mathrm{~mm}$ long. Male smaller than female $(0.75 \mathrm{~mm}$ long) and different in color. Body and head of the males dark brown. Male antennae 8-segmented, with the 1st flagellum almost round and wider than the succeeding segment (Silvestri 1927, Grissell 1979).

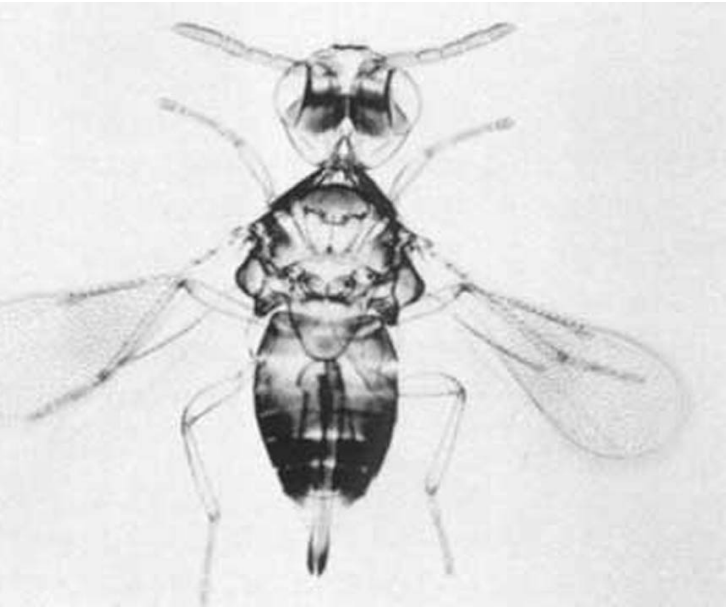

Figure 2. Adult female Encarsia opulenta (Silvestri). Credits: Division of Plant Industry

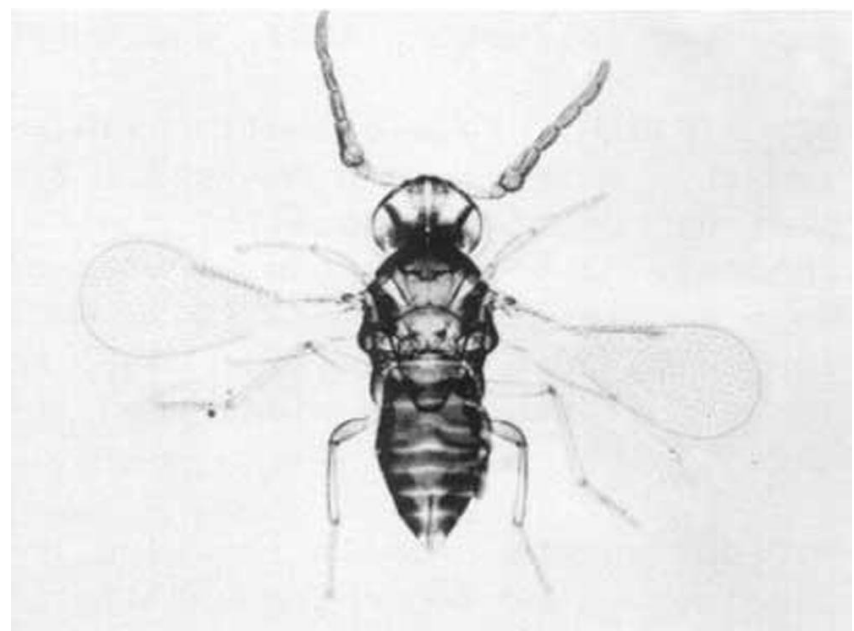

Figure 3. Adult male Encarsia opulenta (Silvestri). Credits: Division of Plant Industry

\section{Biology}

The female can live longer than 30 days with adequate nutrition and displays good searching ability. A mated female lays a single diploid egg in any nymphal stage of the citrus blackfly, but prefers the second stage, and this egg will produce a female. Under laboratory conditions $\left(24^{\circ} \mathrm{C}\right)$ the development from egg to adult requires 30 to 35 days. Virgin females lay haploid eggs in the fully developed larva of the E. opulenta female and produce males (adelpho-parasite). The sex ratio in the field is about 1:7 (male:female). E. opulenta is hyperparasitized by $E$. smithi (Silvestri) that was accidentally introduced to Florida by 1979. In Florida, E. opulenta and Amitus hesperidum (Hymenoptera: Platygastidae) coexist. The latter has a high rate of reproduction, and can produce 60 to 70 progenies per female; thus this species is very effective in suppressing high densities of the citrus blackfly. E. opulenta reproduces very slowly, and can maintain the population of $A$. woglumi at a low level in Florida (Nguyen et al. 1983, Nguyen and Sailer 1987, and Flanders 1969).

\section{Hosts}

Aleurocanthus woglumi Ashby and A. incertus Silvestri are the only hosts reported (Silvestri 1927, Smith et al. 1964).

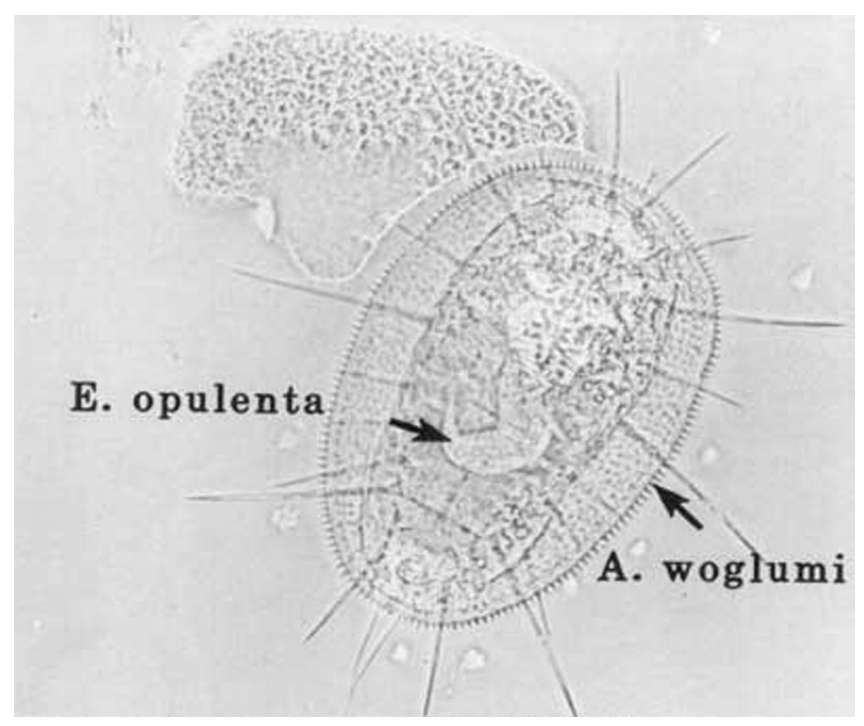

Figure 4. A larva of Encarsia opulenta (Silvestri) in a nymph of the citrus blackfly, Aleurocanthus woglumi Ashby. Credits: Division of Plant Industry

\section{Selected References}

Flanders SE. 1969. Herbert D. Smith's observations on citrus blackfly parasites in India and 
Mexico and the correlated circumstances. Canadian

Entomologist 101: 467-480.

Grissell EE. 1979. The Prospaltella of Florida (Hymenoptera: Aphelinidae). Florida Department of Agriculture and Consumer Services, Division of Plant Industry Entomology Circular 203: 1-4.

Hart WG, Selhime A, Harlan DP, Ingle SJ, Sanchez RM, Rhode RH, Garcia CA, Caballero J, Garcia RL. 1978. The introduction and establishment of parasites of citrus blackfly, Aleurocanthus woglumi in Florida (Homoptera: Aleyrodidae). Entomophaga 23: 361- 366.

Nguyen Ru, Brazzel JR, Poucher C. 1983. Population density of the citrus blackfly, Aleurocanthus woglumi Ashby (Homoptera: Aleyrodidae), and its parasites in urban Florida in 1979-1981. Environmental Entomology 12: 878-884.

Nguyen Ru, Brazzel JR, Poucher C, Sailer RI. 1987. Facultative hyperparasitism and sex determination of Encarsia smithi (Silvestri) (Hymenoptera: Aphelinidae). Annals of the Entomological Society of America 80: 814-819.

Silvestri F. 1927. Contribuzione alla conoscenza degli Aleurodidae (Insecta: Hemiptera) viventi su citrus in Extremo Oriente e dei loro parasiti. Boll. Lab. Zool. Portici. 21: 1-60.

Smith HP, Maltby HL, Jimenez EJ. 1964. Biological control of the citrus blackfly in Mexico. U.S. Department of Agriculture Technical Bulletin No. 1311: 30 pp.

Summy KR, Gilstrap FE, Hart WG, Caballero JM, Saenz I. 1983. Biological control of citrus blackfly (Homoptera: Aleyrodidae) in Texas. Environmental Entomology 12: 782-786. 